\title{
Immunoregulatory peptides in bovine milk
}

\author{
Harsharnjit S. Gill*, F. Doull, K. J. Rutherfurd, and M. L. Cross \\ Milk and Health Research Centre, Institute of Food, Nutrition and Human Health, Massey University, Private Bag 11222, \\ Palmerston North, New Zealand
}

\begin{abstract}
Bovine milk is known to contain a number of peptide fractions that can affect immune function. The vast majority of immunoregulatory peptides that have been characterised are hydrolysate derivatives of major milk proteins. Recent research has also indicated that the metabolic activity of probiotic lactic acid bacteria can generate de novo immunoregulatory peptides from milk, via enzymatic degradation of parent milk protein molecules. In contrast, relatively little is known of endogenous, preformed immunoregulatory peptides in milk that may be relevant to modulating human health. The natural in vivo role of preformed and enzymatically derived peptides is likely to be one of regulation of the neonatal (bovine) gastrointestinal tract immune system, in order to modulate immune function with respect to the development of immunocompetence and avoidance of undesirable immunological responses (e.g. tolerance, and hypersensitivity to nutrients). There is scope for the further characterisation of both the origin and function of milk-derived immunoregulatory peptides, so that their potential to influence human health can be fully appraised. This review highlights our current knowledge of milk-derived immunoregulatory peptides, and outlines areas that are of relevance for further research.
\end{abstract}

Bovine milk: Immunomodulation: Immunoregulation: Peptides

\section{Introduction}

Enzymatic degradation of foodstuffs in the gut releases short-chain peptide sequences from intact proteins, glycoproteins and lipoproteins. In many cases, peptides liberated in this fashion can have important biogenic functions (Schlimme \& Meisel, 1995). In order to effect a biological response, peptides must either transverse the intestinal epithelium and enter circulation, or else bind directly to specific intra-epithelial cell surface receptor sites. There is thus the scope for biogenic peptides, derived from the enzymatic hydrolysis of nitrogen-bearing foods in the gut, to directly affect physiological function through cellular signalling.

Bovine milk comprises a complex mixture of simple, globular and conjugated proteins. Most of these are susceptible to the degradative effects of gastric processing, and extensive hydrolysis takes place upon exposure to enzymes in the gut. These enzymes may be of endogenous origin (i.e. secreted by the digestive system) or exogenous origin (e.g. derived from actively metabolizing gut microflora). In either case, many of the peptides released by enzymatic hydrolysis in the gut have specific biological functions through their ability to bind to (and affect) cellular function (Meisel, 1997).

Several of the biologically active peptides released by enzymatic hydrolysis of milk proteins are known to affect cells of the immune system, and (as a consequence) to affect downstream immunological responses and cellular functions (Coste \& Tome, 1991; Kayser \& Meisel, 1996). In addition, bovine milk contains some immunologically active peptides in preformed or near-formed state, i.e. those which occur naturally in milk and require no or minimal gastric modification to become biologically active (Stoeck et al. 1989, Guimont et al. 1997). The majority of research which has characterised immunologically active peptides has come from in vitro modelling of in vivo gastric processing of milk (Svedberg et al. 1985; Jolles \& Migliore-Samour, 1986). Evidence for immunoregulatory activity has been subsequently derived from both in vitro studies of the direct effects of these peptides on cells of the immune system, and in vivo studies of the effects of peptides delivered by dietary or parenteral routes (Werner et al. 1986; Jolles et al. 1992; Schlimme \& Meisel, 1995). There is now a substantial body of evidence to indicate that bovine milk contains a number of very potent immunoregulatory peptides. This review focuses on evidence for the presence of these peptides, their derivation from individual milk proteins, and describes their effects on the immune system.

\section{Casein-derived peptides \\ $\alpha_{S 1}$-Casein}

Peptide-rich hydrolysates of $\alpha_{\mathrm{S} 1}$-casein have been shown to

* Corresponding author: Professor H. S. Gill, fax +64 6350 5446, email H.S.Gill@massey.ac.nz 
Table 1. Various immunomodulatory activities of peptides derived from $\alpha_{\mathrm{S} 1}$-casein in bovine milk

\begin{tabular}{|c|c|c|c|c|}
\hline Protein & Peptide & Digests & Immune effect & Reference \\
\hline \multirow[t]{5}{*}{$\alpha_{\mathrm{S} 1}$-casein } & & Pancreatin & $\downarrow$ proliferation of lymphocytes & Otani \& Hata (1995) \\
\hline & & Trypsin & $\downarrow$ proliferation of lymphocytes & Otani \& Hata (1995) \\
\hline & & Pepsin/chymotrypsin & $\begin{array}{l}\text { No effect in vitro with mitogen-stimulated } \\
\text { lymphocytes }\end{array}$ & Otani \& Hata (1995) \\
\hline & & Pepsin/trypsin & $\begin{array}{l}\downarrow \text { proliferation of human peripheral blood } \\
\text { mononuclear cells }\end{array}$ & Kayser \& Meisel (1996) \\
\hline & $\begin{array}{l}\text { Thr-Thr-Met-Pro-Leu-Tyr } \\
(194-199)\end{array}$ & Trypsin & $\begin{array}{l}\uparrow \text { antibody formation, } \uparrow \text { phagocytosis, } \\
\downarrow \text { Klebsiella pneumoniae infection }\end{array}$ & $\begin{array}{l}\text { Jolles et al. (1992) } \\
\text { Schlimme \& Meisel (1995) }\end{array}$ \\
\hline \multirow[t]{4}{*}{ Isracidin } & N-terminal sequence $1-23$ & Chymosin & $\begin{array}{l}\text { Protect mice against infection by } \\
\text { Staphylococcus aureus. } \uparrow \text { phagocytic } \\
\text { response in mice infected with } \\
\text { Candida albicans. Protect cows and } \\
\text { sheep against mastitis }\end{array}$ & Lahov \& Regelson (1996) \\
\hline & $\begin{array}{l}\text { Arg-Tyr-Leu-Gly-Tyr-Leu-Glu } \\
(90-96)\end{array}$ & & $\begin{array}{l}\uparrow \text { lymphocyte proliferation, } \uparrow \text { natural killer } \\
\text { activity, } \uparrow \text { neutrophil locomotion }\end{array}$ & $\begin{array}{l}\text { Migliore-Samour \& Jolles (1988) } \\
\text { Elitsur \& Luk (1991) }\end{array}$ \\
\hline & $\begin{array}{l}\text { Arg-Tyr-Leu-Gly-Tyr-Leu } \\
(90-95)\end{array}$ & & $\begin{array}{l}\uparrow \text { lymphocyte proliferation, } \uparrow \text { natural killer } \\
\text { activity, } \uparrow \text { neutrophil locomotion }\end{array}$ & $\begin{array}{l}\text { Migliore-Samour \& Jolles (1988) } \\
\text { Elitsur \& Luk (1991) }\end{array}$ \\
\hline & $\begin{array}{l}\text { Phe-Phe-Val-Ala-Pro-Phe-Pro- } \\
\text { Glu-Val-Phe-Gly-Lys (23-34) }\end{array}$ & & $\begin{array}{l}\text { ACE inhibitor, } \uparrow \text { phagocytosis, } \uparrow \text { protective } \\
\text { response to Klebsiella pneumoniae } \\
\text { infection }\end{array}$ & $\begin{array}{l}\text { Maruyama et al. (1987); } \\
\text { Jolles et al. (1992); } \\
\text { Fiat et al. (1993); Meisel (1997) }\end{array}$ \\
\hline
\end{tabular}

modulate immune function, with different modulatory effects attributable to varying enzymatic digestion regimes. For example Otani \& Hata (1995) have shown that both pancreatin and trypsin digests of $\alpha_{\mathrm{S} 1}$-casein significantly inhibited the proliferative responses of murine splenic lymphocytes and rabbit Peyer's patch cells, whereas digests derived from pepsin and chymotrypsin treatment had no effect when included in in vitro culture with mitogenstimulated cells. Peptide residues derived from the pepsin/ trypsin hydrolysis of $\alpha_{\mathrm{S} 1}$-caseins were also found to significantly suppress mitogen-induced proliferation of human peripheral blood mononuclear cells in vitro (Kayser \& Meisel, 1996). In contrast, trypsin treatment alone of bovine $\alpha_{\mathrm{S} 1}$-casein results in the release of Thr-Thr-MetPro-Leu-Tyr (residues 194-199 C terminal), which has been shown to promote antibody formation and accelerated phagocytosis in vitro, as well as reducing Klebsiella pneumoniae infection in mice in vivo following systemic (intravenous) adminstration (Jolles et al. 1992; Schlimme \& Meisel, 1995). Since trypsin is a major proteinase in pancreatin, the substrate specificity of trypsin seems to be important for the formation of immunoenhancing or suppressing peptides from casein components (Otani \& Hata, 1995).

Chymosin digestion of $\alpha_{\mathrm{S} 1}$-casein results in the immunoenhancing product isracidin (N-terminal sequence 1-23). This peptide has been found to protect mice against infection by Staphylococcus aureus when injected intramuscularly prior to being infected, and to correspondingly stimulate a phagocytic response in mice infected with Candida albicans when injected intravenously in vivo (Lahov \& Regelson, 1996). It has also been found to protect cows and sheep against mastitis, following injection of the peptide into the udder (Lahov \& Regelson, 1996).

Residues 90-96 (Arg-Tyr-Leu-Gly-Tyr-Leu-Glu) and 90-95 (Arg-Tyr-Leu-Gly-Tyr-Leu) of $\alpha_{\mathrm{S} 1}$-casein both have naloxone-inhibitable opioid-like properties. Opioid peptides, such as $\beta$-endorphins, have been demonstrated to exert in vitro and in vivo immunomodulating activities by enhancing lymphocyte proliferative responses, natural killer cell activity and neutrophil locomotion (MiglioreSamour \& Jolles, 1988; Elitsur \& Luk, 1991). Opioid $\mu$ receptors have been demonstrated on $\mathrm{T}$ lymphocytes and human phagocytic leucocytes, and it is possible that absorbed milk peptides with opioid-like activities may be involved in the development of T cell functions and natural killer cell cytotoxicity (Samour \& Jolles, 1988).

The $\alpha_{S 1}$-casein dodecapeptide (Phe-Phe-Val-Ala-ProPhe-Pro-Glu-Val-Phe-Gly-Lys) (residues 23-34) has been shown to stimulate phagocytosis by murine peritoneal macrophages in vitro and consequently to exert a protective effect against Klebsiella pneumoniae challenge in mice after intravenous treatment in vivo (Meisel, 1997). This peptide is also an inhibitor of angiotensin I-converting enzyme (ACE). ACE inhibitors are well known for their antihypertensive properties, but have also been found to prevent cleavage of bradykinin by blocking the conversion of angiotensin I to angiotensin II by ACE (Jolles et al. 1992). Bradykinin acts as a mediator of the acute inflammatory process and is thus able to stimulate macrophages, enhance lymphocyte migration and to induce the secretion of lymphokines from lymphocyte cultures (Maruyama et al. 1987; Fiat et al. 1993).

The various immunomodulatory properties of $\alpha_{\mathrm{S}_{1}}$ casein-derived peptides are summarised in Table 1.

\section{$\beta$-Casein}

As with $\alpha_{\mathrm{S} 1}$-casein, pancreatin and trypsin digests of $\beta$ casein have been shown to significantly inhibit mitogenstimulated proliferative responses of murine splenic lymphocytes and rabbit Peyer's patch cells when included in in vitro cell culture, although no effect has been observed with pepsin and chymotrypsin digests (Otani \& Hata, 1995). Peptide residues derived from the pepsin/trypsin hydrolysis of $\beta$-caseins were also found to significantly suppress the mitogen-induced proliferation of human lymphocytes (Kayser \& Meisel, 1996). In direct contrast, 
Table 2. Various immunomodulatory activities of peptides derived from $\beta$-casein in bovine milk

\begin{tabular}{|c|c|c|c|c|}
\hline Protein & Peptide & Digests & Immune effect & Reference \\
\hline \multirow[t]{7}{*}{$\beta$-casein } & & Pancreatin & $\downarrow$ proliferation of lymphocytes & Otani \& Hata (1995) \\
\hline & & Trypsin & $\downarrow$ proliferation of lymphocytes & Otani \& Hata (1995) \\
\hline & & Pepsin/ chymotrypsin & $\begin{array}{l}\text { No effect in vitro with mitogen- } \\
\text { stimulated lymphocytes }\end{array}$ & Otani \& Hata (1995) \\
\hline & & Pepsin/trypsin & $\downarrow$ proliferation of lymphocytes & Kayser \& Meisel (1996) \\
\hline & $\begin{array}{l}\text { Tyr-Gln-Gln-Pro-Val-Leu- } \\
\text { Gly-Pro-Val-Arg-Gly-Pro- } \\
\text { Phe-Pro-Ile-Ile-Val (193-209) }\end{array}$ & Pepsin/chymosin & $\begin{array}{l}\uparrow \text { proliferative responses in } \\
\text { lymphocytes }\end{array}$ & Migliore-Samour \& Jolles (1988) \\
\hline & $\begin{array}{l}\text { Pro-Gly-Pro-Ile-Pro-Asn } \\
(63-68)\end{array}$ & & $\begin{array}{l}\uparrow \text { antibody formation and } \\
\uparrow \text { phagocytosis }\end{array}$ & $\begin{array}{l}\text { Jolles \& Migliore-Samour (1986); } \\
\text { Jolles et al. (1988); } \\
\text { Migliore-Samour \& Jolles (1988) }\end{array}$ \\
\hline & Leu-Leu-Tyr (191-193) & & $\begin{array}{l}\uparrow \text { antibody formation and } \\
\uparrow \text { phagocytosis, and } \\
\uparrow \text { antigen dependent } \mathrm{T} \text { cell } \\
\text { proliferation }\end{array}$ & $\begin{array}{l}\text { Jolles \& Migliore-Samour (1986); } \\
\text { Jolles et al. (1988); } \\
\text { Migliore-Samour \& Jolles (1988) }\end{array}$ \\
\hline$\beta$-casomorphin & $\begin{array}{l}\text { Tyr-Pro-Phe-Pro-Gly-Pro-Ile- } \\
\text { Pro-Asn-Ser-Leu }(60-70)\end{array}$ & Trypsin & $\begin{array}{l}\downarrow \text { lymphocyte proliferation, } \\
\uparrow \text { mice resistance to } \\
\text { Klebsiella pneumoniae infection. }\end{array}$ & $\begin{array}{l}\text { Elitsur \& Luk (1991); } \\
\text { Kayser \& Meisel (1996) }\end{array}$ \\
\hline$\beta$-casomorphin-7 & $\begin{array}{l}\text { Tyr-Pro-Phe-Pro-Gly-Pro-Ile } \\
(60-66)\end{array}$ & & $\begin{array}{l}\downarrow \text { lymphocyte proliferation at low } \\
\text { conc. } \uparrow \text { lymphocyte proliferation } \\
\text { at high conc. }\end{array}$ & Kayser \& Meisel (1996) \\
\hline \multirow[t]{2}{*}{$\beta$-casokinin-10 } & $\begin{array}{l}\text { Tyr-GIn-GIn-Pro-Val-Leu-Gly- } \\
\text { Pro-Val-Arg (193-202) }\end{array}$ & & $\begin{array}{l}\downarrow \text { lymphocyte proliferation at low } \\
\text { conc. } \uparrow \text { lymphocyte proliferation } \\
\text { at high conc. } \\
\text { ACE inhibitor }\end{array}$ & $\begin{array}{l}\text { Maruyama et al. (1987); } \\
\text { Kayser \& Meisel (1996) }\end{array}$ \\
\hline & $\begin{array}{l}\text { Ala-Pro-Tyr-Pro-Gln-Arg } \\
(177-183)\end{array}$ & & ACE inhibitor & Maruyama et al. (1987) \\
\hline
\end{tabular}

the C-terminal sequence 193-209 of $\beta$-casein (obtained from a pepsin/chymosin digest of bovine casein) has been shown to directly stimulate proliferation of rat lymphocytes in vitro in the absence of extraneous mitogens or antigens (Meisel, 1997).

Hydrolysis of $\beta$-casein results in the hexapeptide ProGly-Pro-Ile-Pro-Asn (residues 63-68) and the tripeptide Leu-Leu-Tyr (LLY, residues 191-193). Both peptides have been shown to promote antibody formation and accelerated phagocytosis by murine peritoneal macrophages in vitro, but LLY also enhances antigen-dependent T cell proliferation (Jolles \& Migliore-Samour, 1986, 1988; MiglioreSamour \& Jolles, 1988).

$\beta$-Casomorphins are fragments of the $\beta$-casein sequence $60-70$, which have opiate-like properties and have been shown to modulate the immune system. $\beta$-Casomorphins were originally isolated from human and bovine $\beta$-casein following in vitro trypsin hydrolysis (Elitsur \& Luk, 1991). To be biologically active, $\beta$-casomorphin needs to be released from its precursor $\beta$-casein, and it is thought that this process takes place in vivo via enzymatic hydrolysis in the gut lumen (Elitsur \& Luk, 1991). Indeed $\beta$-casomorphin has been found in the intestinal aspirates of human volunteers who had ingested bovine milk (Svedberg et al. 1985). Elitsur \& Luk (1991) found a significant in vitro suppressive effect of $\beta$-casomorphins on human lamina propria-derived lymphocyte proliferation at concentrations as low as $10 \mu \mathrm{M}$. This antiproliferative effect was reversed by addition to culture of the opiate receptor antagonist naloxone (Elitsur \& Luk, 1991).

In vivo, $\beta$-casomorphins have been shown to have an opposite effect on immune function to the above in vitro work, in that they have been shown to enhance the resistance of mice to Klebsiella pneumoniae, probably through a stimulation of peritoneal macrophages. However, as with the in vitro work, administration in vivo of an opioid antagonist to mice resulted in the suppression of this stimulatory effect, suggesting an active opioid receptorbinding site for the biologically active peptide (Parker et al. 1984; Elitsur \& Luk, 1991).

Depending on the concentration, $\beta$-casomorphin-7 (residues $60-66$ of $\beta$-casein) and $\beta$-casokinin-10 (residues 193-202 of $\beta$-casein) can exhibit bipolar modulatory effects on human peripheral blood lymphocyte proliferation. In in vitro culture with mitogen-stimulated $\mathrm{T}$ lymphocytes, both peptides have been shown to suppress proliferation at low concentrations but to enhance proliferation at high concentrations (Kayser \& Meisel, 1996).

$\beta$-Casein has ACE-inhibitory fragments that have been shown to stimulate phagocytosis by murine peritoneal macrophages and to exert a protective effect against Klebsiella pneumoniae infection in mice after intravenous treatment with doses as low as $0.5 \mathrm{mg} / \mathrm{kg}$ (Jolles et al. 1992; Schlimme \& Meisel, 1995). $\beta$-Casokinin-10 and heptapeptide Ala-Val-Pro-Tyr-Pro-Gln-Arg (residues 177183 of $\beta$-casein) have been found to inhibit ACE which, like residues $23-34$ of bovine $\alpha_{\mathrm{S} 1}$-casein, may act on the immune system by preventing the breakdown of bioactive bradykinin (Maruyama et al. 1987).

The various immunomodulatory properties of $\beta$-caseinderived peptides are summarised in Table 2.

$$
\kappa \text {-Casein }
$$

Bovine $\kappa$-caseinoglycopeptide (residues 106-169, CGP) prepared from $\kappa$-casein digested with chymosin, has been shown to be a potent inhibitor of lipopolysaccharide (LPS)-induced and phytohaemagglutinin (PHA)-induced 
Table 3. Various immunomodulatory activities of peptides derived from $\kappa$-casein in bovine milk

\begin{tabular}{|c|c|c|c|c|}
\hline Protein & Peptide & Digests & Immune effect & Reference \\
\hline \multicolumn{5}{|l|}{$\kappa$-casein } \\
\hline к-caseinoglycopeptides & $\begin{array}{l}\text { Residues } 106-169 \\
\text { of } \kappa \text {-casein }\end{array}$ & Chymosin & $\downarrow$ proliferation of lymphocytes & Otani et al. (1995) \\
\hline Fractionated CGP & & & $\begin{array}{l}\downarrow \text { PHA-induced proliferative response } \\
\text { on mouse splenic cells. Inhibition } \\
\text { increases with increasing number } \\
\text { of NANA residues (up to 5) }\end{array}$ & Otani et al. (1995) \\
\hline Fractionated CGP & & & $\begin{array}{l}\downarrow \text { LPS-induced proliferative response } \\
\text { on mouse splenic cells. Most potent } \\
\text { at } 2 \text { NANA residues }\end{array}$ & Otani et al. (1995) \\
\hline \multirow[t]{3}{*}{ Para-к-casein } & $\begin{array}{l}\text { Phe-Phe-Ser-Asp- } \\
\text { Lys-(17-21) } \\
\text { Tyr-Gly (38-39) }\end{array}$ & Trypsin & $\begin{array}{l}\uparrow \text { antibody formation and } \uparrow \text { phagocytosis } \\
\text { in vitro } \\
\uparrow \text { proliferation of lymphocytes }\end{array}$ & $\begin{array}{l}\text { Jolles \& Migliore-Samour (1986); } \\
\text { Jolles et al. (1988) } \\
\text { Kayser \& Meisel (1996); } \\
\text { Meisel (1997) }\end{array}$ \\
\hline & & Pepsin/trypsin & $\uparrow$ proliferation of lymphocytes & Sutas et al. (1996a) \\
\hline & & $\begin{array}{l}\text { Lactobacillus GG } \\
\text { strain enzymes + } \\
\text { pepsin/trypsin }\end{array}$ & $\downarrow$ proliferation of lymphocytes & Sutas et al. (1996a) \\
\hline
\end{tabular}

proliferation of murine splenic lymphocytes in vitro, and also to suppress in vitro antibody production in murine spleen cell cultures (Otani et al. 1995). Otani et al. (1995) also confirmed that both LPS- and PHA-induced proliferative responses of rabbit Peyer's patch cells were suppressed by the presence of this peptide in vitro. It is known that LPS directly stimulates B lymphocytes, whereas PHA stimulates helper T lymphocytes, and it is therefore likely that CGP down-regulates the immune system by suppressing the proliferative responses of both lymphocyte subsets (Otani et al. 1995).

Otani et al. (1995) characterised seven fractions of CGP with zero to five $N$-acetylneuraminic acid (NANA) residues, which had different inhibitory effects from the unfractionated CGP on both LPS- and PHA-induced proliferative responses of murine spleen cells. The inhibitory effect on PHA-induced proliferative responses increased with increasing numbers of NANA residues, whereas inhibition of LPS-induced proliferation was highest when the CGP fraction had two NANA residues. Both inhibitory effects decreased significantly after neuraminidase digestion. These findings indicate that both the carbohydrate portions (particularly the NANA residues) and the polypeptide portions are essential for inhibitory effects on LPS- and PHA-induced proliferative responses of murine spleen cells (Otani et al. 1995).

In direct contrast to the work of Otani and colleagues, Sutas et al. (1996a) found that peptides derived from the pepsin-trypsin hydrolysis of $\mathrm{\kappa}$-casein significantly enhanced the mitogen-induced proliferation of human lymphocytes. Furthermore, the $\mathrm{\kappa}$-casein/trypsin-derived peptide Phe-Phe-Ser-Asp-Lys (residues 17-21, bovine para-к-casein [1-105 region of $\kappa$-casein]) has been shown to promote antibody formation and accelerated phagocytic activity of murine and human macrophages in vitro (Jolles \& Migliore-Samour, 1986; Jolles et al. 1988). In addition, Tyr-Gly (residues 38 and 39 of $\kappa$-casein) is another immunomodulating peptide, which can in principle pass across the intestine in quantitatively significant amounts to reach local lymphocytes. The effects of TyrGly on the proliferation of human peripheral blood lymphocytes, activated with concanavalin A, have been examined in vitro, and Tyr-Gly was shown to significantly enhance cellular proliferation (Kayser \& Meisel, 1996; Meisel, 1997).

\section{Lactic acid bacteria-derived bioactive peptides}

Although $\mathrm{\kappa}$-casein has been shown to possess immunosuppressive properties against lymphocytes, a study by Sutas et al. (1996a) demonstrated that the metabolic activity of probiotic lactic acid bacteria (LAB) can assist in de novo formation of immunostimulatory peptides from $\mathrm{\kappa}$-casein. When к-casein was hydrolysed with Lactobacillus GG strain enzymes, followed by pepsin-trypsin treatment, the peptide derivatives were found to enhance the mitogen responsiveness of human lymphocytes, when included in in vitro cell culture. In contrast, similar treatment of $\alpha_{\mathrm{S} 1^{-}}$and $\beta$-casein failed to reverse the suppressive effects of $\kappa$-casein on human lymphocyte function. This study has highlighted the ability of LAB to influence the enzymatic generation of immunoregulatory peptides from milk (Sutas et al. 1996a).

Sutas et al. (1996b) further investigated whether bovine caseins, degraded by enzymes of an intestinal bacterial strain Lactobacillus GG, could regulate cytokine production by anti-CD3 antibody-stimulated human peripheral blood mononuclear cells, when included in in vitro cell culture. Purified casein derivatives up-regulated interleukin-4 (IL-4) and interferon- $\gamma$ (IFN- $\gamma$ ) production, whereas Lactobacillus GG-degraded casein down-regulated the IL-4 production with no effect on IFN- $\gamma$. These results clearly demonstrate that intestinal bacteria may modify the immunomodulatory properties of native food proteins.

The various immunomodulatory properties of $\kappa$-caseinderived peptides are summarised in Table 3.

\section{Whey proteins \\ $\alpha$-Lactalbumin}

Murine humoral immune responses to sheep and human red blood cells are known to be enhanced by a hydrolysed 
Table 4. Various immunomodulatory activities of whey proteins and other milk-derived peptides

\begin{tabular}{|c|c|c|c|c|}
\hline Protein & Peptide & Digests/fractions & Immune effect & Reference \\
\hline $\begin{array}{l}\text { Whey proteins } \\
\alpha \text {-Lactalbumin }\end{array}$ & $\begin{array}{l}\text { Hydrolysed } \\
\alpha \text {-lactalbumin }\end{array}$ & & $\begin{array}{l}\uparrow \text { mice immune response to } \\
\text { SRBCs and HRBCs }\end{array}$ & Bounous \& Kongshavn (1985) \\
\hline$\beta$-Lactoglobulin & $\beta$-Lactoglobulin & & $\begin{array}{l}\text { Carries retinoic acid. } \\
\downarrow \text { lymphocyte blastogenesis }\end{array}$ & $\begin{array}{l}\text { Guimont et al. (1997); } \\
\text { Elitsur et al. (1997) }\end{array}$ \\
\hline Lactoferrin & $\begin{array}{l}\text { Residues } 17-41 \\
\text { of lactoferrin } \\
\text { (lactoferricin B) }\end{array}$ & & $\begin{array}{l}\downarrow \text { IL- } 6 \text { response when stimulated } \\
\text { by LPS. } \uparrow \text { release of IL- } 8 \text { from } \\
\text { leucocytes }\end{array}$ & $\begin{array}{l}\text { Mattsby-Baltzer et al. (1996); } \\
\text { Shinoda et al. (1996) }\end{array}$ \\
\hline Glycophosphopeptide & & Gel filtration, anion exchange & Strong mitogenic activity & Yun et al. (1996) \\
\hline Milk growth factor & & $\begin{array}{l}\text { Cation exchange, HPLC, } \\
\text { and size exclusion with HPLC }\end{array}$ & $\downarrow$ proliferation of lymphocytes & Stoeck et al. (1989) \\
\hline
\end{tabular}

$\alpha$-lactalbumin diet, and this effect involves the modulation of both B lymphocyte and T helper cell activities (Bounous \& Kongshavn, 1985). Commercially available dietary hydrolysed $\alpha$-lactalbumin has also been shown to enhance immune responses to the $\mathrm{T}$ cell-independent antigen TNPFicoll, which can stimulate B lymphocytes in the absence of $\mathrm{T}$ lymphocyte co-operation (Bounous \& Kongshavn, 1982). However, the biologically active peptides responsible for this immunomodulation were not identified further in these studies.

\section{$\beta$-Lactoglobulin}

$\beta$-Lactoglobulin is the most abundant of the whey proteins and is a carrier of small hydrophobic molecules, including retinoic acid, which is a potential modulator of lymphocyte responses (Guimont et al. 1997). Trans-retinoic acid has been found by Elitsur et al. (1997) to enhance mitogenstimulated proliferation of human colonic lamina propriaderived lymphocytes (LPL). This effect was abolished when LPL preparations were depleted of macrophages, suggesting that trans-retinoic acid might affect accessory cells during lymphocyte proliferation.

\section{Lactoferrin}

Human lactoferrin has been shown to cause differentiation of $\mathrm{CD}^{-} / \mathrm{CD}^{-}$lymphocytes to $\mathrm{CD} 4^{+}$helper T-lymphocytes in vitro. The lymphocyte receptor-binding region for human lactoferrin resides in an N-terminal peptide (4-52) released by the action of trypsin. The structural homology between bovine and human lactoferrin, together with the proven ability of native bovine lactoferrin to suppress lymphocyte blastogenesis in vitro, predicts a lymphocyte receptor-binding region for bovine lactoferrin similar to that of human lactoferrin (Schanbacher et al. 1997).

Bovine lactoferricin B (residues 17-41 of lactoferrin) has also been found to suppress interleukin- 6 production by a human monocytic cell line in response to LPS stimulation in vitro (Mattsby-Baltzer et al. 1996). Both bovine lactoferrin and lactoferricin have the ability to stimulate the release of the neutrophil-activating chemokine interleukin-8 from human polymorphonuclear leucocytes (Shinoda et al. 1996). The fraction of bovine lactoferrin depleted of lactoferricin has no stimulatory effect (Miyauchi et al. 1998)

\section{Glycophosphopeptide}

Yun et al. (1996) isolated a peptidic fraction from cheese whey protein concentrate, by gel filtration and anion exchange chromatography, which showed high natural mitogenic activity toward murine splenocytes in vitro. The fraction was found to contain calcium, inorganic phosphorus and carbohydrate, indicating the active component to be a glycophosphopeptide (GPP). The carbohydrate component of GPP containing N-linked oligosaccharide chains may be important in the strong mitogenic activity. None of the mitogenic factors that have been found in cheese whey or bovine milk have the same characteristics as seen in the GPP found by Yun et al. (1996). It remains uncertain whether GPP is formed during the course of cheese production or is an endogenous peptide which is contained already in raw milk and then concentrated in cheese whey.

The various immunomodulatory properties of whey protein-derived peptides are summarised in Table 4.

\section{Other peptides}

\section{Tuftsin}

Tuftsin is a tetrapeptide Thr-Lys-Pro-Arg (residues 289292), which is derived from endopeptidase and leukokininase cleavage of the heavy chain $\mathrm{F}_{\mathrm{c}}$ region of IgG. Human Igderived tuftsin has a variety of immunoregulatory effects, including stimulation of leucocyte chemotaxis and phagocyte motility, enhancement of phagocyte oxidative metabolism and antigen processing, and increase in monocyte- and NK cell-mediated tumour cell cytotoxicity (Werner et al. 1986). Although the immunoregulatory role of bovine Igderived tuftsin remains to be determined, the high immunoglobulin content of bovine milk and colostrum would suggest that this might be a fruitful area for future study.

\section{Proline-rich polypeptide}

Proline-rich polypeptide (PRP) isolated from ovine colostral whey has been found to possess regulatory properties that stimulate or suppress immune responses. A nonapeptide fragment Val-Glu-Ser-Tyr-Val-Pro-Leu-Phe-Pro (VESYVPLFP) has been isolated from a chymotryptic digest of ovine PRP. VESYVPLFP along with the corresponding synthetic peptide and its C-terminal penta- 
and hexapeptides, shows immunoregulatory activities in mice similar to native PRP, including enhancement of splenic antibody responses to foreign erythrocyte antigens (SRBC) when administered $3 \mathrm{~h}$ before immunisation with SRBC (Janusz et al. 1987). Ovine PRP has been shown to induce cytokine production by murine macrophages (Blach-Olszewska \& Janusz, 1997) and also to induce growth and differentiation of resting B lymphocytes, but has not been shown to induce detectable Ig isotype switching in murine cells in vitro (Julius et al. 1988).

Bovine PRP has not yet been studied in any great detail, but if it is found to have similar properties to ovine PRP, then it will have great potential in the development of functional foods.

\section{Milk growth factor}

Milk growth factor (MGF) is a monomeric immunoregulatory peptide, which has been isolated from bovine milk and purified to a high degree by three-stage column chromatography (Stoeck et al. 1989). MGF shows complete N-terminal sequence homology with bovine TGF- $\beta 2$ and has been found to universally suppress human $\mathrm{T}$ lymphocyte functions in vitro, including mitogen- and interleukin-2 stimulated cellular proliferation, recall proliferative responses to tetanus toxoid antigen, and proliferation of an antigen-specific human T cell clone (Stoeck et al. 1989).

\section{Conclusions}

The potential for bovine milk to generate immunoregulatory peptides is now well established. In many cases, both the bioactive molecules and their effects have been characterised via in vitro and in vivo studies of immune function (e.g. the work of Otani and colleagues on $\mathrm{k}$ casein-derived CGP). The majority of research so far has focused on the effect of immunoactive peptides in vitro, and in many instances the effects of these peptides in vivo has yet to be shown. The precise mode of action of most immunoactive peptides on the immune system also remains to be determined.

It is likely that the in vivo significance of immunomodulatory peptides is to regulate immune function in the neonatal bovine, such that the gastrointestinal tract immune system develops full functionality in the absence of unwanted effects, including tolerance to pathogen-derived antigens or hypersensitivity to nutrient molecules. However, the comparatively new field of de novo generation of milk-derived peptides via LAB biometabolism remains underexplored, and further research is required in this area to identify novel immunoregulatory peptides formed by probiota. Similarly, the notion that milk contains preformed peptides with immunoregulatory activity (e.g. GPP, MGF) is gaining momentum. Further technological advances in the field of low-molecular-weight peptide fractionation should facilitate the identification of endogenous immunoregulatory peptides in milk. Finally, immunoregulatory peptides have been demonstrated in milk or major milk proteins of other species (e.g. human tuftsin and ovine PRP), but the regulatory role of these molecules derived from bovine milk remains an unexplored area. In all cases, there is scope for clinical scientists to prove that demonstrable immunoregulatory properties of milk-derived peptides can correspond to tangible improvements in human health.

\section{References}

Blach-Olszewska Z \& Janusz M (1997) Stimulatory effect of ovine colostrinine (a proline-rich polypeptide) on interferons and tumor necrosis factor production by murine resident peritoneal cells. Archivum Immunologiae et Therapiae Experimentalis 45, 43-47.

Bounous G \& Kongshavn PAL (1982) Influence of dietary proteins on the immune system of mice. Journal of Nutrition 112, 1747-1755.

Bounous G \& Kongshavn PAL (1985) Differential effect of dietary protein type on the $\mathrm{B}$ cell and $\mathrm{T}$ cell responses in mice. Journal of Nutrition 115, 1403-1408.

Coste M \& Tome D (1991) Milk peptides with physiological activities. II Opioid and immunostimulating peptides derived from milk proteins. Lait 71, 241-247.

Elitsur Y \& Luk GD (1991) Beta-casomorphin (BCM) and human colonic lamina propria lymphocyte proliferation. Clinical and Experimental Immunology 85, 493-497.

Elitsur Y, Neace C, Liu X, Dosescu J \& Moshier JA (1997) Vitamin A and retinoic acids immunomodulation on human gut lymphocytes. Immunopharmacology 35, 247-253.

Fiat AM, Migliore-Samour D, Jolles P, Drouet L, Sollier CB \& Caen J (1993) Biologically active peptides from milk proteins with emphasis on two examples concerning antithrombotic and immunomodulating activities. Journal of Dairy Science 76, 301-310.

Guimont C, Marchall E, Girardet JM \& Linden G (1997) Biologically active factors in bovine milk and dairy byproducts, Influence on cell culture. Critical Reviews in Food Science and Nutrition 374, 393-410.

Janusz M, Wieczorek Z, Spiegel K, Kubik A, Szewczuk Z, Siemion I \& Lisowski J (1987) Immunoregulatory properties of synthetic peptides, fragments of a proline-rich polypeptide (PRP) from ovine colostrum. Molecular Immunology 24, 1029.

Jolles P, Fiat A-M, Migliore-Samour D, Drouet L \& Caen J (1992) Peptides from milk proteins implicated in antithrombosis and immunomodulation. In New Perspectives in Infant Nutrition, Symposium Antwerp, pp. 160-172 [B Renner and G Sawatzki, editors]. New York: Thieme Medical Publications.

Jolles P \& Migliore-Samour D (1986) Preparation of immunological agents by treating lipid-free bovine casein with proteolytic enzyme and fractionating the product. Patent Assignee: RhonePoulenc Sante. WPI Acc No, 86-037423/06, United States Patent 4851 509, European Patent 170550.

Jolles P, Migore-Samour D \& Parker F (1988) Immuno stimulant substances derived from bovine casein and compositions containing the same. Patent Assignee: Rhone-Poulenc Sante. United States Patent 4777243.

Julius MH, Janusz M \& Lisowski J (1988) A colostral protein that induces the growth and differentiation of resting B lymphocytes. Journal of Immunology 140, 1366.

Kayser H \& Meisel H (1996) Stimulation of human peripheral blood lymphocytes by bioactive peptides derived from bovine milk proteins. FEBS Letters 383, 18-20.

Lahov E \& Regelson W (1996) Antibacterial and immunostimulating casein-derived substances from milk, casecidin, isracidin peptides. Food and Chemical Toxicology 34, 131-145.

Maruyama S, Mitacki H, Awaya J, Kurono M, Tomizuka N \& Suzuki H (1987) Angiotensin I-converting enzyme inhibitory 
activity of the C-terminal hexapeptide of alpha S1 casein Agricultural and Biological Chemistry 51, 2557-2561.

Mattsby-Baltzer I, Roseanu A, Motaas C, Elverfors J, Engberg I \& Hanson LA (1996) Lactoferrin or a fragment thereof inhibits the endotoxin-induced interleukin-6 response in human monocytic cells. Pediatric Research 40, 257-262.

Meisel H (1997) Biochemical properties of regulatory peptides derived from milk proteins. Biopolymers 43, 119-128.

Migliore-Samour D \& Jolles P (1988) Casein, a prohormone with an immunomodulating role for the newborn? Experientia $\mathbf{4 4}$ $188-193$

Miyauchi H, Hashimoto S, Nakajima M, Shinoda I, Fukuwatari Y \& Hayasawa H (1998) Bovine lactoferrin stimulates the phagocytic activity of human neutrophils, identification of its active domain. Cellular Immunology 187, 34-37.

Otani H \& Hata I (1995) Inhibition of proliferative responses of mouse spleen lymphocytes and rabbit Peyer's patch cells by bovine milk caseins and their digests. Journal of Dairy Research 62, 339-348.

Otani H, Monnai M, Kawasaki Y, Kawakami H \& Tanimoto M (1995) Inhibition of mitogen-induced proliferative responses of lymphocytes by bovine $\mathrm{\kappa}$-caseinoglycopeptides having different carbohydrate chains. Journal of Dairy Research 62, 349357.

Parker F, Migliore-Samour D \& Floc'h F (1984) Immunostimulating hexapeptide from human casein, amino acid sequence, synthesis and biological properties. European Journal of Biochemistry 145, 677-682.

Schanbacher FL, Talhouk RS \& Murray FA (1997) Biology and origin of bioactive peptides in milk. Livestock Production Science 50, 105-123.

Schlimme E \& Meisel H (1995) Bioactive peptides derived from milk proteins. Structural, physiological and analytical aspects. Die Nahrung 39, 1-20.

Shinoda I, Takase M, Fukuwatari Y, Shimamura S, Koller M \& Konig W (1996) Effects of lactoferrin and lactoferricin on the release of interleukin 8 from human polymorphonuclear leucocytes. Bioscience, Biotechnology and Biochemistry 60, 521-523.

Stoeck M, Ruegg C, Miescher S, Carrel S, Cox D, Fliedner V, Alkan S \& VonFliedner V (1989) Comparison of the immunosuppressive properties of milk growth factor and transforming growth factors beta1 and beta2. Journal of Immunology 143, 3258-3265.

Sutas Y, Hurme M \& Isolauri E (1996b) Down-regulation of antiCD3 antibody-induced IL-4 production by bovine caseins hydrolysed with Lactobacillus GG-derived enzymes. Scandinavian Journal of Immunology 43, 687-689.

Sutas Y, Soppi E \& Korhonen H (1996a) Suppression of lymphocyte proliferation in vitro by bovine caseins hydrolyzed with Lactobacillus casei GG-derived enzymes. Journal of Allergy and Clinical Immunology 98, 216-224.

Svedberg J, DeHaas J, Leimenstoll G, Paul F \& Teschemacher H (1985) Demonstration of $\beta$-casomorphin immunoreactive materials in in vitro digests of bovine milk and in small intestine contents after bovine milk ingestion in adult humans. Peptides 6, 825 .

Werner GH, Floc'h F, Migliore-Samour D \& Jolles P (1986) Immunomodulating peptides. Experientia 42, 521-531.

Yun SS, Sugita-Konishi Y, Kumagai S, Yamauchi K, (1996) Isolation of mitogenic glycophosphopeptides from cheese whey protein concentrate. Bioscience, Biotechnology and Biochemistry 60, 429-433. 